Research Article

\title{
Genotoxicity and mutagenicity of Echinodorus macrophyllus (chapéu-de-couro) extracts
}

\author{
Leonardo S. Vidal $^{1, \#}$, Adriana M. Alves ${ }^{1, \#}$, Ricardo M. Kuster ${ }^{2}$, Claudia Lage ${ }^{1}$ and Alvaro C. Leitão ${ }^{1}$ \\ ${ }^{1}$ Laboratório de Radiobiologia Molecular, Instituto de Biofísica Carlos Chagas Filho, \\ Universidade Federal do Rio de Janeiro, Rio de Janeiro, RJ, Brazil. \\ ${ }^{2}$ Núcleo de Pesquisas de Produtos Naturais, Universidade Federal do Rio de Janeiro, Rio de Janeiro, \\ RJ, Brazil.
}

\begin{abstract}
Echinodorus macrophyllus, commonly known as chapéu-de-couro, is a medicinal plant used in folk medicine to treat inflammation and rheumatic diseases. In this work, we used short-term bacterial assays based on the induction of SOS functions to examine the genotoxicity and mutagenicity of an aqueous extract of $E$. macrophyllus leaves. Whole extract and an ethyl acetate fraction showed similar genotoxicity and caused an $\sim 70$-fold increase in lysogenic induction. The extract also gave a positive result in the SOS chromotest with an increase of 12 -fold in $\beta$-Galactosidase enzymatic units. There was a strong trend towards base substitutions and frameshifts at purine sites in the mutations induced by the extract in Escherichia coli (CC103 and CC104 strains) and Salmonella typhimurium test strains (22-fold increase in histidine revertants in TA98 strain). Since reactive oxygen species may be implicated in aging process and in degenerative diseases, we used antioxidant compounds as catalase, thiourea and dipyridyl in the lysogenic induction test. All this compounds were able to reduce the induction factor observed in the treatment with chapéu-de-couro, thus suggesting that the genotoxicity and mutagenicity were attributable to the production of reactive oxygen species that targeted DNA purines.
\end{abstract}

Key words: Echinodorus macrophyllus, genotoxicity, mutagenesis, reactive oxygen species.

Received: October 21, 2009; Accepted: March 2, 2010.

\section{Introduction}

In recent years, there has been a widespread increase in the use of medicinal plants or natural products because of their potentially beneficial effect on human health. However, there is little information on the mutagenic effects of most of the active principles found in these medicinal plants. Many plants may be effective phytomedicines but need to be exhaustively investigated to detect any toxic side effects. This is particularly important because many plants synthesize toxic substances for defense against viruses, bacteria and fungi and these compounds could have potentially deleterious effects in humans.

The biological effects of medicinal plant extracts are complex because of the presence of additional substances generated during processing and/or through the use of additives (Sugimura, 1982). Since many constituents found in industrial food/phytomedicine preparations may be muta-

Send correspondence to Alvaro C. Leitão. Laboratório de Radiobiologia Molecular, Instituto de Biofísica Carlos Chagas Filho, Av. Carlos Chagas Filho 373, Centro de Ciências da Saúde, Bloco G, Cidade Universitária, 21941-902 Rio de Janeiro, RJ, Brazil. E-mail: acleitao@biof.ufrj.br.

\#These authors contributed equally to this work. genic it is necessary to assess whether they can induce DNA damage in order to minimize the risks of cellular lesions during human consumption (Halliwell and Gutteridge, 1989). Many of these compounds have been associated with the generation of harmful reactive oxygen species (ROS) (Leitão and Braga, 1994; Fonseca et al., 2000).

Echinodorus macrophyllus, an aquatic plant of the family Alismataceae, known in Brazil as chapéu-de-couro, is widely used in the production of a very popular Brazilian soft drink. An aqueous extract of E. macrophyllus is used to treat rheumatic diseases that are usually characterized by exacerbated $\mathrm{T}$ and B lymphocyte responses. Pinto et al. (2007) observed immunosuppression of the T-cell response in mice treated orally with chapéu-de-couro extract for 7 days.

Since massive ROS production leading to DNA lesions is a major cause of toxic effects caused by plant extracts and products, in this work we used bacterial tests to evaluate the genotoxicity and mutagenicity of chapéu-decouro extract. Genotoxicity was assessed using the inductest (Moreau et al., 1976) and the SOS chromotest (Quillardet et al., 1982), whereas mutagenicity was as- 
sessed by the reverse mutation test with histidine-auxotrophic strains of Salmonella typhimurium, i.e., the Ames test (Maron and Ames, 1983), the WP2 mutagenicity test (Blanco et al., 1998) and lactose mutagenesis assays (Cupples and Miller, 1989; Cupples et al., 1990). The results obtained indicate that the extract has marked genotoxic and mutagenic effects that are clearly associated with structural alterations in purine targets.

\section{Material and Methods}

\section{Bacterial strains}

The Escherichia coli strains used in this work are listed in Table 1 and the $S$. typhimurium strains are listed in Table 2.

\section{Bacterial media}

Bacteria were grown overnight in LB medium at $37^{\circ} \mathrm{C}$ in a shaking incubator (Miller, 1992). After this incubation, an aliquot of this culture was inoculated into fresh LB medium $(1: 40 \mathrm{v} / \mathrm{v})$ until the bacteria reached the exponential phase of growth.

The E. coli survival and infective center production assays were done by plating bacterial samples in LB medium and LB medium containing $10 \mu \mathrm{g}$ of ampicillin $/ \mathrm{mL}$ (LB-amp), respectively. Both media were solidified with $1.5 \%$ Difco bacto agar. We used E medium (Vogel and Bonner, 1956) solidified with $1.5 \%$ Difco bacto agar and supplemented with histidine for the Ames test (Maron and Ames, 1983) and with tryptophan for the WP2 mutagenicity test (Blanco et al., 1998). A selective minimal medium containing $0.4 \%$ lactose was used for the Lac+-revertant mutagenesis assay (Cupples and Miller, 1989; Cupples et al., 1990).

\section{Preparation of Echinodorus macrophyllus infusion}

Infusions of E. macrophyllus were prepared by the same standard procedure used by the pharmaceutical industry to obtain the phytomedicine for commercial use. Dried leaves of certified E. macrophyllus plants were kindly provided by a local pharmaceutical industry (Laboratório Simões Ltd., Rio de Janeiro, Brazil). A crude aqueous infusion was prepared by adding boiling water to grated dried leaves $(200 \mathrm{mg} / \mathrm{mL})$ for $10 \mathrm{~min}$, after which the mixture was filtered, lyophilized and stored at $-20^{\circ} \mathrm{C}$ until further use.

\section{Partition of the extract by solubility}

The lyophilized extract was successively partitioned by an extraction method based on organic solvents of increasing polarity (hexane, chloroform, ethyl acetate and butanol). The extract was obtained by macerating leaves with $70 \%$ ethanol for 15 days, and the dry ethanolic extract was suspended in bidistilled water and subjected to successive partitions with the specified organic solvents. The

Table 1 - Escherichia coli strains used in this work.

\begin{tabular}{|c|c|c|}
\hline Designations & Relevant genotype & Reference \\
\hline WP2s & WP2 $u v r \mathrm{~A} / \mathrm{pKM} 101 a m p^{\mathrm{R}}$ & Blanco et al. (1998) \\
\hline IC203 & WP2 oxyR / pKM101 $a m p^{\mathrm{R}}$ & Blanco et al. (1998) \\
\hline IC204 & $\mathrm{WP} 2 \Delta(u m u \mathrm{DC}) c a t^{\mathrm{R}}$ & Blanco et al. (1998) \\
\hline IC206 & $\mathrm{WP} 2 \Delta(u m u \mathrm{DC}) m u t \mathrm{Y} c a t^{\mathrm{R}}$ & Blanco et al. (1998) \\
\hline IC208 & $\mathrm{WP} 2 \Delta(u m u \mathrm{DC}) m u t \mathrm{Y}$ oxy $\mathrm{R} c a t^{\mathrm{R}}$ & Blanco et al. (1998) \\
\hline $\mathrm{CC} 101$ & $\mathrm{P} 90 \mathrm{C}$ ara $\Delta(\text { lac proB })_{\mathrm{XIII}}(\mathrm{A}: \mathrm{T} \rightarrow \mathrm{C}: \mathrm{G})$ & Cupples and Miller (1989) \\
\hline $\mathrm{CC} 102$ & $\mathrm{P} 90 \mathrm{C} \operatorname{ara} \Delta(\text { lac proB })_{\mathrm{XIII}}(\mathrm{G}: \mathrm{C} \rightarrow \mathrm{A}: \mathrm{T})$ & Cupples and Miller (1989) \\
\hline $\mathrm{CC} 103$ & $\mathrm{P} 90 \mathrm{C}$ ara $\Delta(\text { lac proB })_{\mathrm{XIII}}(\mathrm{G}: \mathrm{C} \rightarrow \mathrm{C}: \mathrm{G})$ & Cupples and Miller (1989) \\
\hline $\mathrm{CC} 104$ & $\mathrm{P} 90 \mathrm{C}$ ara $\Delta(\text { lac proB })_{\mathrm{XIII}}(\mathrm{G}: \mathrm{C} \rightarrow \mathrm{T}: \mathrm{A})$ & Cupples and Miller (1989) \\
\hline $\mathrm{CC} 105$ & $\mathrm{P} 90 \mathrm{C}$ ara $\Delta(\text { lac proB })_{\mathrm{XIII}}(\mathrm{A}: \mathrm{T} \rightarrow \mathrm{T}: \mathrm{A})$ & Cupples and Miller (1989) \\
\hline CC106 & $\mathrm{P} 90 \mathrm{C}$ ara $\Delta(\text { lac proB })_{\mathrm{XIII}}(\mathrm{A}: \mathrm{T} \rightarrow \mathrm{G}: \mathrm{C})$ & Cupples and Miller (1989) \\
\hline $\mathrm{CC} 107$ & $\mathrm{P} 90 \mathrm{C}$ ara $\Delta(\text { lac proB })_{\mathrm{XIII}}(+1 \mathrm{G})$ & Cupples et al. (1990) \\
\hline $\mathrm{CC} 108$ & $\mathrm{P} 90 \mathrm{C}$ ara $\Delta(\text { lac proB })_{\mathrm{XIII}}(-1 \mathrm{G})$ & Cupples et al. (1990) \\
\hline $\mathrm{CC} 109$ & $\mathrm{P} 90 \mathrm{C}$ ara $\Delta(\text { lac proB })_{\mathrm{XIII}}(-2(\mathrm{CG}))$ & Cupples et al. (1990) \\
\hline $\mathrm{CC} 110$ & $\mathrm{P} 90 \mathrm{C}$ ara $\Delta(\text { lac proB })_{\mathrm{XIII}}(+1 \mathrm{~A})$ & Cupples et al. (1990) \\
\hline $\mathrm{CC} 111$ & $\mathrm{P} 90 \mathrm{C}$ ara $\Delta(\text { lac proB })_{\mathrm{XIII}}(-1 \mathrm{~A})$ & Cupples et al. (1990) \\
\hline WP2s $(\lambda)$ & $\mathrm{WP} 2 u v r \mathrm{~A}(\lambda) \operatorname{trp} \mathrm{E}$ & Our laboratory stock \\
\hline RJF013 & [B/r SR 714] $u v r \mathrm{D} 3 \operatorname{trp} \mathrm{E} a m p^{\mathrm{R}}$ & Our laboratory stock \\
\hline PQ37 & uvrA rfa sfi $\mathrm{A}:: l a c \mathrm{Z}$ & Quillardet and Hofnung (1985) \\
\hline
\end{tabular}


Table 2 - Salmonella typhimurium strains used in this work.

\begin{tabular}{lll}
\hline Designations & Relevant genotype & Reference \\
\hline TA97 & hisD6610/ hisO1242 - $u u v r \mathrm{~B} r f a \mathrm{pKM} 101\left(a m p^{R}\right)$ & Maron and Ames (1983) \\
TA98 & $h i s \mathrm{D} 3052-\Delta u v r \mathrm{~B} r f a \mathrm{pKM} 101\left(a m p^{\mathrm{R}}\right)$ & Maron and Ames (1983) \\
TA100 & $h i s \mathrm{G} 46-\Delta u v r \mathrm{~B} r f a \mathrm{pKM} 101\left(a m p^{\mathrm{R}}\right)$ & Maron and Ames (1983) \\
TA102 & $h i s \mathrm{G} 428$-wild type $r f a \mathrm{pKM} 101\left(a m p^{\mathrm{R}}\right) \mathrm{pAQ} 1\left(t e t^{\mathrm{R}}\right)$ & Maron and Ames (1983) \\
\hline
\end{tabular}

samples obtained with each partitioning were subsequently screened for genotoxicity in the Inductest.

\section{Chemicals}

Catalase (Sigma Chemical Co., St. Louis, MO, USA) and thiourea (Indústrias Químicas Merck S/A, Rio de Janeiro, Brazil) were dissolved in bidistilled water. Dipyridyl (Sigma) was dissolved in 10\% ethanol and then diluted in bidistilled water for each experiment.

\section{Genotoxicity studies}

\section{Lysogenic induction assay}

Strains WP2s $(\lambda)$ and RJF013 of E. coli B/r (Table 1) were used in the lysogenic induction assay in a protocol similar to the quantitative inductest developed by Moreau et al. (1976). Each assay was done in duplicate, with the results representing the average of at least three experiments. The level of induction was expressed as the induction factor, i.e., the ratio of the number of infective centers after treatment divided by the number of spontaneous infective centers.

The positive controls in the genotoxicity and mutagenicity assays consisted of exposing the cultures to either a single UV-C dose $\left(2 \mathrm{~J} / \mathrm{m}^{2}\right)$ or a single concentration $(0.1 \mu \mathrm{g} /$ plate $)$ of 4-nitroquinolein-1-oxide (4-NQO).

\section{SOS chromotest assay}

Strain PQ37 of E. coli K-12 (Table 1) was used in the SOS chromotest studies, according to the protocol developed by Quillardet and Hofnung (1985). The results represent the average of at least three experiments. $\beta$-Galactosidase activity (expressed in enzymatic units) was plotted against the absorbance at $420 \mathrm{~nm}$ after each treatment. Viability was determined based on the mean values of survival inactivation (data not shown).

\section{Mechanism of action underlying the genotoxicity of the extract}

The mechanism of action involved in the genotoxicity was investigated in experiments in which the lysogenic induction was measured after exposure to a fixed amount of chapéu-de-couro extract (150 mg/plate) in the absence (control) or presence of antioxidant compounds. Since many plant extracts are capable of generating damaging ROS, the ability of the chapéu-de-couro extract to stimulate the production of these radical was examined by adding increasing concentrations of catalase, thiourea or dipyridyl to the incubations. Each assay was done in duplicate and the results represent the average of at least three experiments.

\section{Mutagenicity studies}

\section{Reverse mutagenesis to histidine prototrophy (Ames test)}

This assay was done as described by Maron and Ames (1983), using the histidine S. typhimurium auxotroph mutant strains TA97, TA98, TA100 and the wild type strain TA102 (Table 2). Each assay was done in duplicate and the results represent the average of at least three experiments. Mutagenesis induced by chapéu-de-couro extract in each strain was expressed as the fold increase in the number of scored $\mathrm{his}^{+}$-induced revertants versus the spontaneous revertants.

\section{Reverse mutagenesis to tryptophan prototrophy (WP2 test)}

This assay was done as described by Blanco et al. (1998), using the tryptophan auxotroph strains WP2s, IC203, IC204, IC206 and IC208 of E. coli (Table 1). Each assay was done in duplicate and the results represent the average of at least three independent experiments. Mutagenesis induced by chapéu-de-couro extract in each strain was expressed as the fold increase in the number of scored trp ${ }^{+}$-induced revertants versus the spontaneous revertants.

\section{Lactose mutagenesis assay}

This assay was done as described by Cupples and Miller (1989) and Cupples et al. (1990) using different strains constructed to detect specific base pair substitutions and frameshift mutations in the E. coli lacZ locus. Mutagenic activity was expressed as the number of revertants per $10^{8}$ cells. The scored spontaneous revertants were subtracted from the induced revertents to determine the effective mutagenesis frequency.

\section{Results}

\section{Genotoxicity induced by chapéu-de-couro extract}

Figure 1 shows the prophage induction caused by different amounts of chapéu-de-couro extract. Maximal rates of prophage induction (corresponding to an $\sim 70$-fold increase above the spontaneous background) were observed with $50 \mathrm{mg}$ of extract/plate. In the SOS chromotest, a concentration of $150 \mathrm{mg}$ of lyophilized extract $/ \mathrm{mL}$ increased 
the enzymatic activity to 33 units (a 12-fold increase above spontaneous enzymatic activity) (Figure 2). The results obtained with the Chromotest reinforced those of the

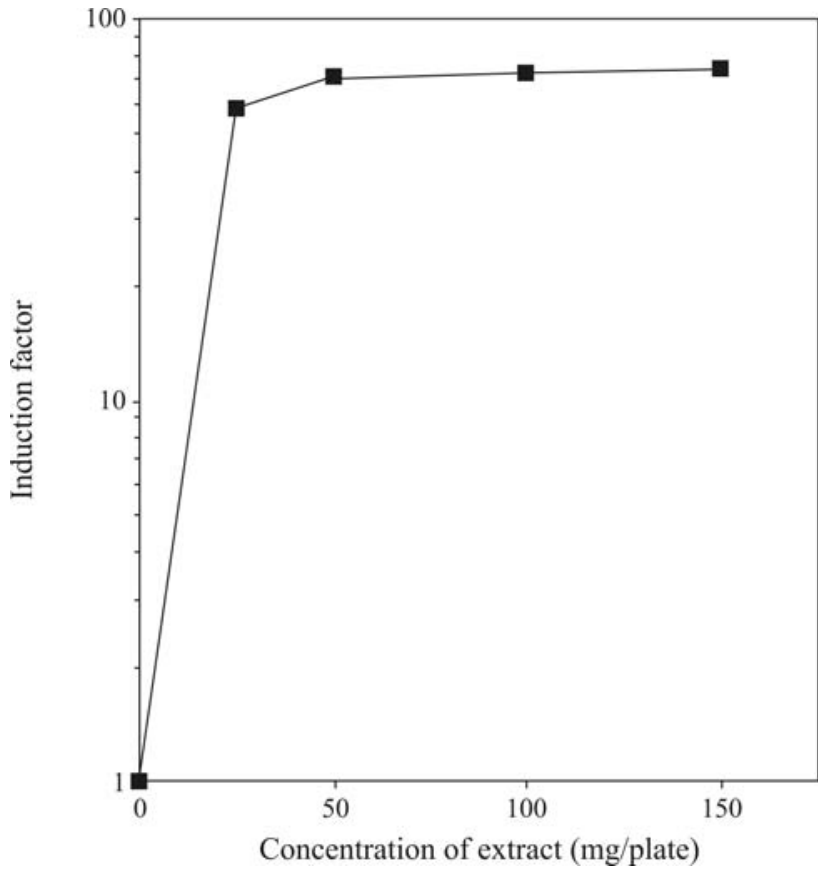

Figure 1 - Dose-response curve for prophage induction as a function of the concentration of a lyophilized chapéu-de-couro extract. Cultures of E. coli WP2s $(\lambda)$ in the exponential phase of growth were diluted $\left(10^{-4}\right)$ and $0.1 \mathrm{~mL}$ samples were pre-incubated at $37^{\circ} \mathrm{C}$ for $20 \mathrm{~min}$ with the specified concentrations of lyophilized extract. The mixtures were then poured onto LB-amp plates together with $0.3 \mathrm{~mL}$ of indicator strain (RJF013) and $3 \mathrm{~mL}$ of molten soft agar.

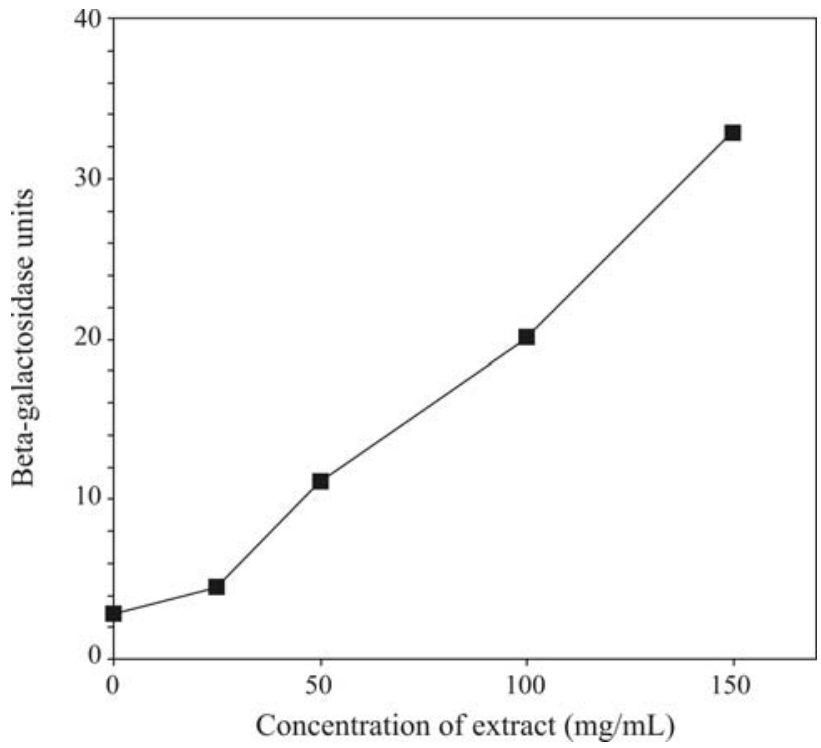

Figure 2 - Induction of $\beta$-galactosidase in PQ37 strain after treatment with different concentrations of a lyophilized extract of chapéu-de-couro. The extent of $\beta$-galactosidase induction by the extract was calculated by using the equation developed by Quillardet and Hofnung (1985) after measuring the absorbance at $420 \mathrm{~nm}$. Viability was assessed by survival inactivation (data not shown) inductest assay and indicated that chapéu-de-couro extract was genotoxic to bacterial cells.

\section{Suppression of the genotoxicity of chapéu-de-couro extract}

To examine the mechanism by which chapéu-decouro extract exerts its genotoxicity, different antioxidant agents were added to the bacterial cultures simultaneously with the extract $(150 \mathrm{mg} /$ plate). Figure 3 shows the inhibitory effects of catalase, dipyridyl and thiourea on the genotoxicity of the extract in the inductest assay. A single unit of catalase inhibited lysogenic induction by $50 \%$, whereas nearly $100 \%$ inhibition was achieved with as little as 5 units of enzyme activity (Figure 3a). Thiourea and dipyridyl concentrations $>25 \mathrm{mM}$ and $>1 \mathrm{mM}$, respectively, also completely blocked lysogenic induction (Figure $3 \mathrm{~b}$ and $3 \mathrm{c}$, respectively).

\section{Genotoxicity of fractions of chapéu-de-couro extract}

To identify which fraction of chapéu-de-couro extract accounted for the genotoxicity of the whole mixture, inductest assays were done with fractions obtained by solubilizing the lyophilized extract in solvents of variable polarities. Figure 4 shows that the ethyl acetate fraction of chapéu-de-couro was more effective in inducing the prophage in $E$. coli WP2s $(\lambda)$ when compared to the aqueous fraction (80-fold and 3-fold increases, respectively, at $150 \mathrm{mg} / \mathrm{plate}$ ). The other fractions (hexane, chloroform and butanol) did not induce the prophage (data not shown). This ethyl acetate fraction is expected to contain aglycone flavonoids such as quercetin and lutheolin, and phenylpropanoids (Zhang et al., 2001).

\section{Mutagenicity assessed by the Ames test}

The mutagenicity of chapéu-de-couro extract assessed by the Ames test is shown in Figure 5. A 22-fold increase in the number of spontaneous revertants was observed after treatment of $E$. coli strain TA98 with lyophilized extract $(150 \mathrm{mg} /$ plate $)$. This finding suggested that GC sites are targeted by components present in the extract. The extract was not mutagenic in strains TA97, TA100 and TA102. At the concentrations tested, the extract was not lethal to any of the strains examined (data not shown).

\section{Mutagenicity in WP2s Trp strains}

The lyophilized extract of chapéu-de-couro did not increase the number of revertants in the wild-type WP2s strain at any of the concentrations tested. A deficiency in OxyR protein function caused the number of revertants in strain IC203 to increase 6- and 10-fold, relative to the spontaneous rate after treatment with 25 and $50 \mathrm{mg}$ of extract/plate, respectively. Since the oxyR mutation renders this strain more sensitive to oxidative stress caused by $\mathrm{H}_{2} \mathrm{O}_{2}$ or other organic peroxides these findings suggest that some of the mutagenicity may be mediated by peroxide activity. 

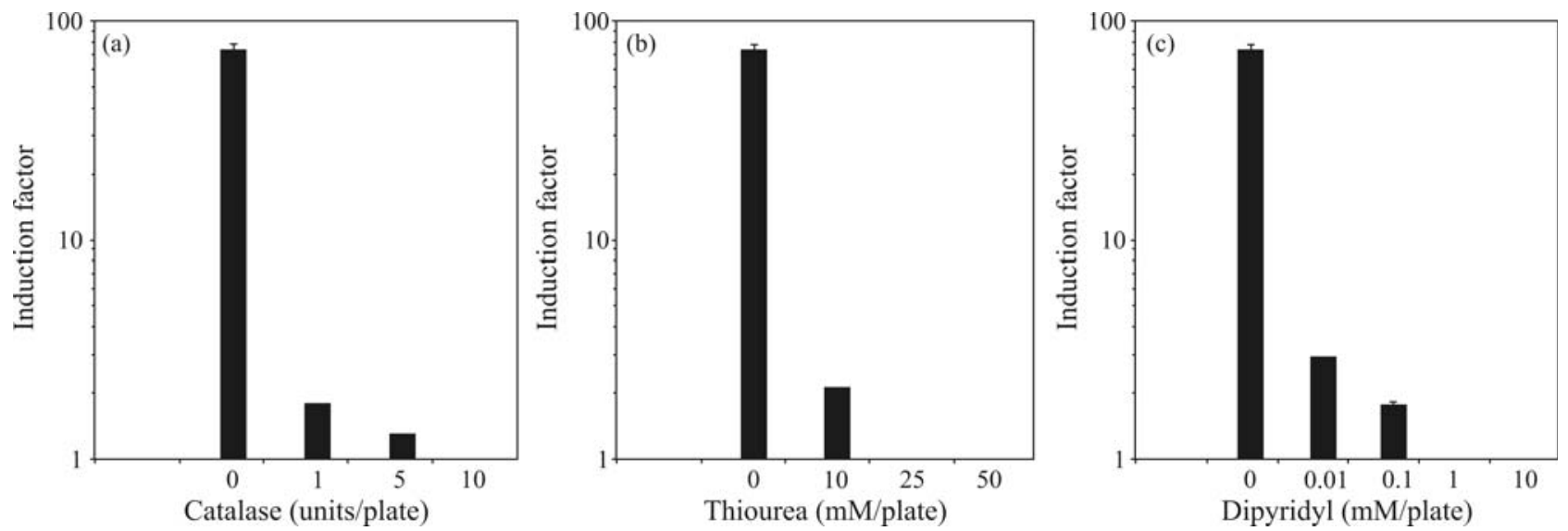

Figure 3 - (a) Effect of catalase on the prophage-inducing activity of a lyophilized extract of chapéu-de-couro. Cultures of E. coli WP2s( $\lambda$ ) in the exponential phase of growth were diluted $\left(10^{-4}\right)$ and $0.1 \mathrm{~mL}$ samples were incubated with lyophilized extract $(150 \mathrm{mg} / \mathrm{plate})$ together with the indicated amounts of catalase for $20 \mathrm{~min}$ at $37^{\circ} \mathrm{C}$. The mixtures were then poured onto LB-amp plates together with $0.3 \mathrm{~mL}$ of indicator strain RJF013 and $3 \mathrm{~mL}$ of molten soft agar. The bars represent the standard errors. (b) Effect of thiourea on the prophage-inducing activity of a lyophilized extract of chapéu-de-couro. Cultures of $E$. coli WP2s $(\lambda)$ in the exponential phase of growth were diluted $\left(10^{-4}\right)$ and $0.1 \mathrm{~mL}$ samples were incubated with lyophilized extract $\left(150 \mathrm{mg} /\right.$ plate) together with the indicated amounts of thiourea for $20 \mathrm{~min}$ at $37^{\circ} \mathrm{C}$. The mixtures were then poured onto LB-amp plates together with $0.3 \mathrm{~mL}$ of indicator strain RJF013 and $3 \mathrm{~mL}$ of molten soft agar. The bars represent the standard errors. (c) Effect of dipyridyl on the prophage-inducing activity of a lyophilized extract of chapéu-de-couro. Cultures of $E$. coli WP2s $(\lambda)$ in the exponential phase of growth were diluted $\left(10^{-4}\right)$ and $0.1 \mathrm{~mL}$ samples were incubated with lyophilized extract $(150 \mathrm{mg} / \mathrm{plate})$ together with the indicated amounts of dipyridyl for $20 \mathrm{~min}$ at $37^{\circ} \mathrm{C}$. The mixtures were then poured onto LB-amp plates together with $0.3 \mathrm{~mL}$ of indicator strain RJF013 and $3 \mathrm{~mL}$ of molten soft agar. The bars represent the standard errors.

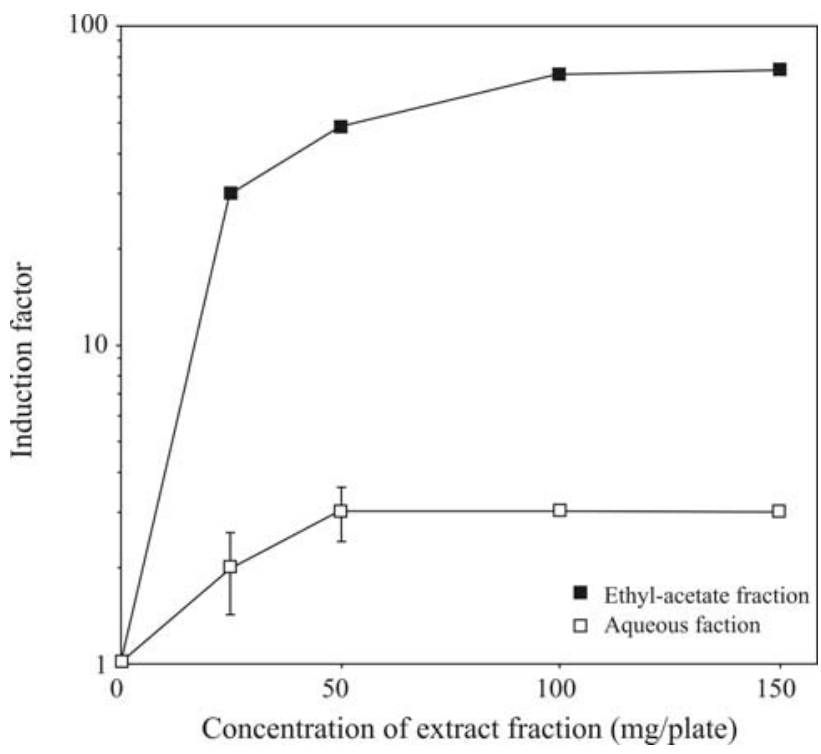

Figure 4 - Dose-response curve for prophage induction by chapéu-decouro extracts of different polarities. Cultures of $E$. coli WP2s $(\lambda)$ in the exponential phase of growth were diluted $\left(10^{-4}\right)$ and $0.1 \mathrm{~mL}$ samples were incubated for $20 \mathrm{~min}$ at $37{ }^{\circ} \mathrm{C}$ with the indicated amounts of each fraction. The mixtures were then poured onto LB-amp plates together with $0.3 \mathrm{~mL}$ of indicator strain (RJF013) and $3 \mathrm{~mL}$ molten soft agar. The bars represent the standard errors.

Similar amounts of extract ( 25 and $50 \mathrm{mg} /$ plate) also increased the number of revertants in strain IC208 by 6 - and 13-fold, respectively. This induction probably resulted from a deficiency in UmuDC and MutY functions. Remarkably, at the highest amount of extract tested

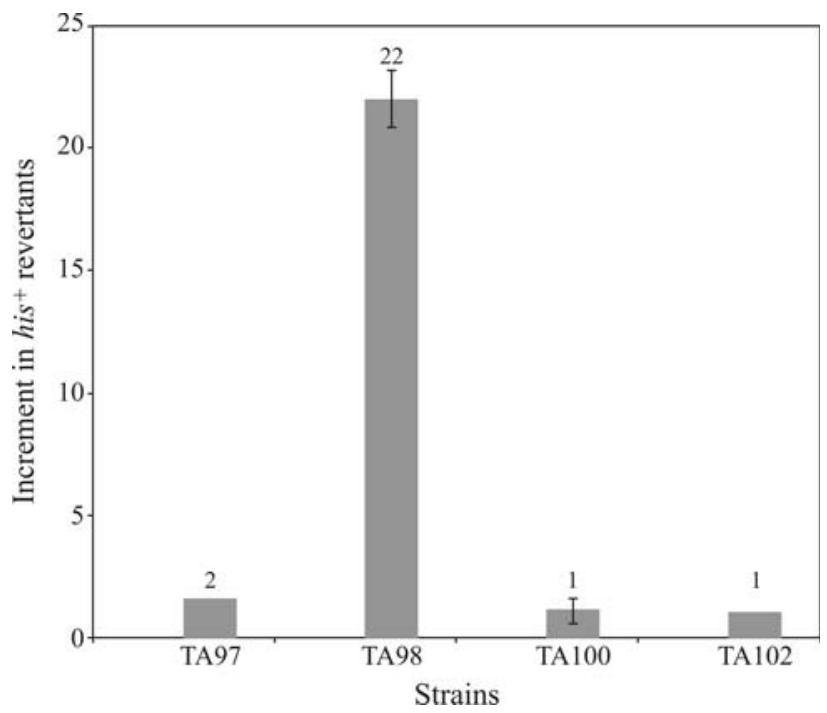

Figure 5 - Mutagenic activity of a lyophilized extract of chapéu-de-couro. Cultures of S. typhimurium in the stationary phase of growth $(0.1 \mathrm{~mL}$ samples) were pre-incubated for $20 \mathrm{~min}$ at $37^{\circ} \mathrm{C}$ with $150 \mathrm{mg}$ of lyophilized extract/plate. After pre-incubation, the mixtures were poured onto E medium plates together with $2 \mathrm{~mL}$ of molten top agar supplemented with his-bio solution $(200 \mu \mathrm{L})$. Viability was assessed by survival inactivation (data not shown).

(150 mg/plate) there was a 10 -fold increase in the number of revertants in $u m u$ DC-deficient strain IC204, which suggested that SOS-independent pathways may also be involved in this response. The extract did not significantly affect strain IC206, although there was a discrete 5-fold increase in mutagenesis after treatment with $>50 \mathrm{mg}$ of ex- 
tract/plate (Figure 6); as with strain IC204, this finding may indicate the involvement of SOS-independent mechanisms in this damage.

\section{Lactose mutagenesis assay: definition of mutagenic hot spots}

To investigate which DNA bases were targets for components of the chapéu-de-couro extracts, the lactose mutagenesis assay was done using $E$. coli strains with specific $\mathrm{Lac}^{-} \rightarrow \mathrm{Lac}^{+}$reversion phenotypes (Figure 7a,b). As shown in Figure 7a, the chapéu-de-couro extract specifically reverted strains CC103 (534 revertants) and CC104 (222 revertants) to the $\mathrm{Lac}^{+}$phenotype.

\section{Discussion}

The results of this study indicate that chapéu-decouro (E. macrophyllus) extract is genotoxic and mutagenic to $E$. coli. The extract induced $\lambda$ prophage in the $E$. coli strain WP2s $(\lambda)$ and induced the expression of $\beta$-galactosidase in E. coli strain PQ37. The treatment of $S$. typhimurium strains CC103 and CC104 with chapéu-decouro extract indicated that GC sites may be the targets for mutagenic compounds since these strains are sensitive to base substitution at purine sites.

ROS are deleterious to many organisms and have been implicated in aging and in degenerative diseases such as cancer (Harman, 1956; Valko et al., 2007). The consecutive univalent reduction of molecular oxygen to water produces three active intermediates: superoxide anion $\left(\mathrm{O}_{2}{ }^{-}\right)$, hydrogen peroxide $\left(\mathrm{H}_{2} \mathrm{O}_{2}\right)$ and hydroxyl radical $\left(\mathrm{OH}^{*}\right)$.

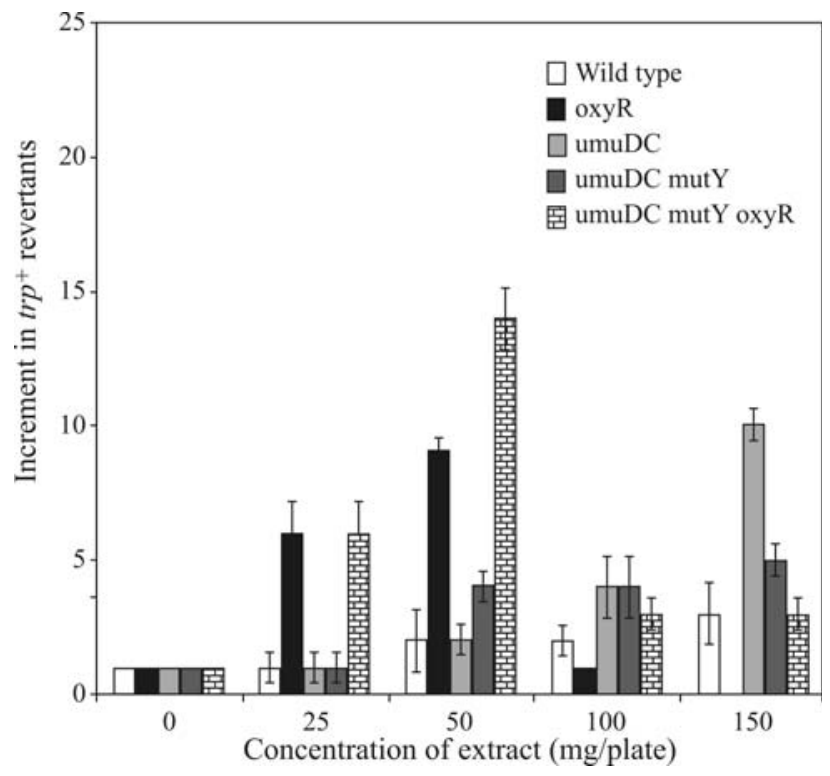

Figure 6 - Mutagenic activity of a lyophilized extract of chapéu-de-couro. Cultures of $E$. coli in the stationary phase of growth $(0.1 \mathrm{~mL}$ samples $)$ were pre-incubated for $20 \mathrm{~min}$ at $37^{\circ} \mathrm{C}$ with the indicated concentration of lyophilized extract. After pre-incubation, the mixtures were poured onto $\mathrm{E}$ medium plates containing tryptophan $(0.5 \mathrm{mg} / \mathrm{L})$ and $2.5 \mathrm{~mL}$ of molten top agar.
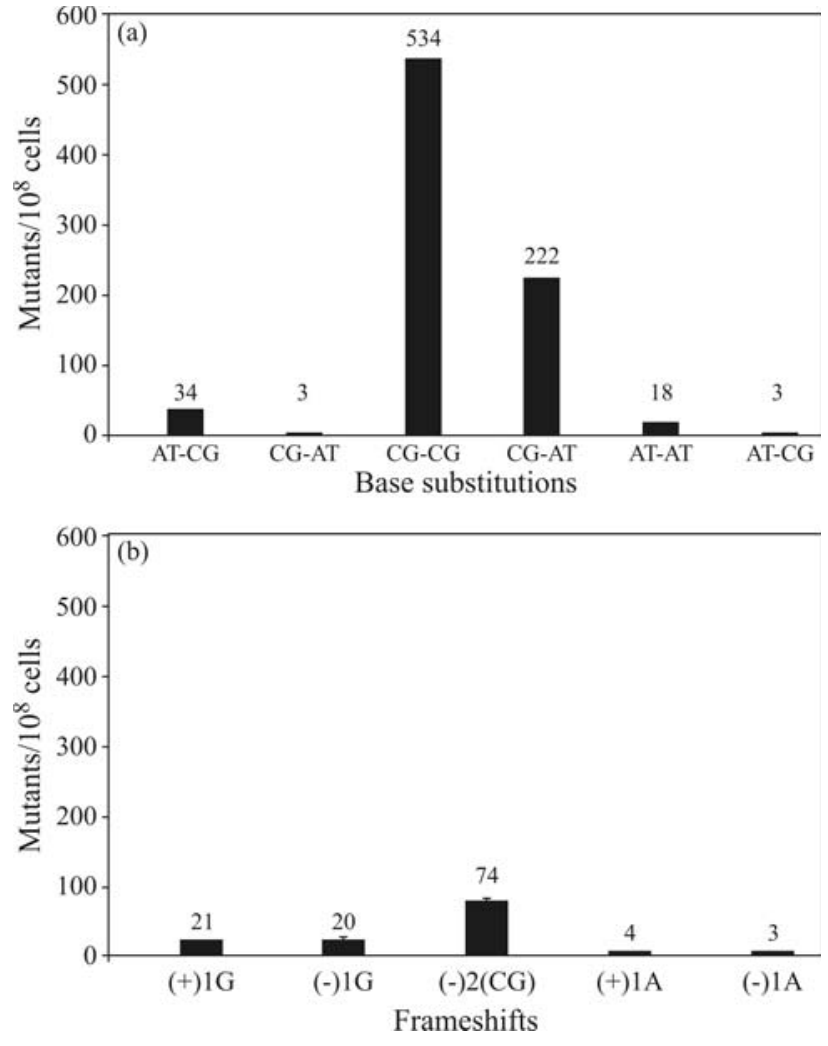

Figure 7 - Mutagenic activity of a lyophilized extract of chapéu-de-couro. Cultures of $E$. coli in the exponential phase of growth were pre-incubated for $20 \mathrm{~min}$ at $37{ }^{\circ} \mathrm{C}$ with $150 \mathrm{mg}$ of lyophilized extract/plate. After pre-incubation, aliquots of $200 \mu \mathrm{L}$ were added to $2 \mathrm{~mL}$ of LB medium and incubated overnight prior to pouring onto minimal medium plates containing $0.4 \%$ lactose. (a) base substitutions, (b) frameshifts.

These oxygen species are potent oxidants of lipids, proteins and nucleic acids, and may be related to the genotoxicity of several substances present in human foods (Ames and Gold, 1991).

Previous studies have shown that catalase reduces the genotoxicity of tea, mate, guaraná and coffee infusions, which suggests the participation of ROS in the toxicity of these extracts (Fonseca et al., 1994; Leitão and Braga, 1994; Fonseca et al., 2000). Our results indicate that ROS may also be involved in the genotoxicity of chapéu-decouro extract since lysogenic induction was effectively inhibited by catalase (10 U/plate). This finding suggests that hydrogen peroxide present in, or generated by, compounds in the extract may have a role in the resulting genotoxicity.

The genotoxicity and mutagenicity of coffee may be attributable to the presence of hydrogen peroxide and the hydroxyl radical $\left(\mathrm{OH}^{\circ}\right)$, as suggested by the use of free radical scavengers (Fujita et al., 1985; Ariza et al., 1988; Ruiz-Laguna and Pueyo, 1999). As shown here, thiourea suppressed the genotoxicity of chapéu-de-couro extract, indicating a possible role for $\mathrm{OH}^{*}$ in this effect. This conclusion agrees with the previously reported ability of pretreatment with thiourea to protect $E$. coli against the lethal effects of $\mathrm{H}_{2} \mathrm{O}_{2}$ (Brandi et al., 1989). $\mathrm{OH}^{\circ}$ can be generated 
by the oxidation of transition metals that act as reducing agents for $\mathrm{H}_{2} \mathrm{O}_{2}$ in the Fenton reaction (Imlay et al., 1988). The fact that dipyridyl reduces $\mathrm{OH}^{*}$ production via the Fenton reaction strongly supports the hypothesis that chapéu-de-couro extract may exert its genotoxicity through ROS formation.

Some compounds previously recognized as carcinogens in eukaryotic assays have tested negative when screened in bacterial mutagenic assays, even when genotoxic in the inductest, e.g., several metallic substances (Rossman et al., 1984). A previous study found no mutagenicity for chapéu-de-couro extract (up to $50 \mathrm{mg} / \mathrm{plate}$ ) in S. typhimurium TA strains (da Costa Lopes et al., 2000). As shown here with the Ames test, the chapéu-de-couro extract $(150 \mathrm{mg} /$ plate $)$ was mutagenic only in strain TA98, which indicates that GC sites are the main targets in DNA. According to Gatehouse et al. (1994), the ability of a substance to double the number of revertants compared to the spontaneous rate is the most widely accepted criterion for considering a substance to be mutagenic in the Ames test. Based on this definition, we conclude that the chapéude-couro extract is mutagenic.

To confirm the results obtained with the Ames test, experiments were done using tryptophan auxotrophic $E$. coli WP2s strains with different DNA repair backgrounds.

One of the main oxidative damages induced by endogenous and exogenous compounds is the formation of 8-oxoguanine (8-oxo-dG). This damage is unrelated to cellular lethality in E. coli. Rather, this alteration is highly mutagenic, especially in the absence of MutT, MutM (Fpg) or MutY proteins. The importance of these proteins in minimizing such oxidative damage is attested to by their absolute evolutionary conservation (Tchou and Grollman, 1993; Blanco et al., 1998). The mutagenic activity of the chapéu-de-couro extract apparently targeted GC sites since the Ames assay was positive in TA98, and reversion to tryptophan prototrophy was greater in strains harboring defective anti-oxidative responses. In the case of the mut $\mathrm{Y}$ strain, the specific increase in $\mathrm{G}: \mathrm{C} \rightarrow \mathrm{T}: \mathrm{A}$ transversions suggested the accumulation of 8-oxoguanine and of 8-oxo-dG:A mispairings.

To examine the DNA-specific targets further, a group of $E$. coli strains carrying specific point mutations in the lactose operon were tested against the chapéu-de-couro extract. Again, the results indicated that compounds in the chapéu-de-couro extract were able to induce transversions at $\mathrm{GC}$ sites, especially $\mathrm{G}: \mathrm{C} \rightarrow \mathrm{C}: \mathrm{G}$ and $\mathrm{G}: \mathrm{C} \rightarrow$ T:A mutations, as well as GC deletions (Figure 7a,b). In many respects, the spectrum of mutations generated by the extract resembled that induced by ROS attack of guanine targets (McBride et al., 1991; Retel et al., 1993; Akasaka and Yamamoto, 1994). The latter noted that the increase in mutation frequency after treatment with $\mathrm{H}_{2} \mathrm{O}_{2}$ correlated closely with the increase in 8-oxoguanine formation.
McBride et al. (1991) observed G-to-C transversions followed by C-to-T transitions in an analysis of ROSinduced mutations in the lac Z gene, with G-to-T transversions being the most prevalent mutational events. Analysis of sequences from 82 mutants showed base substitutions to be the most prominent mutational event in 70 cases, with 63 of these being G:C transversions. The G:C-to-C:G transversion was the most frequent ( 28 cases), followed by 26 cases of G:C-to-T:A. These authors suggested that G:C-to-T:A transversions were a consequence of mispairing between a modified guanine, probably 8oxo-guanine, and deoxyadenosine. In contrast, the origin of G:C-to-C:G transversions was attributed to the formation of unidentified damage generated by $\mathrm{H}_{2} \mathrm{O}_{2}$.

In addition to the mechanisms indicated above, the components of the chapéu-de-couro extract may also directly generate abasic sites in DNA, particularly through guanine residues. This could explain the G-to-C transversions observed after treatment with chapéu-de-couro extract. These transversions were also observed by Murry (1986) after treatment with hydroxylaminopurine (HAP), a compound with anti-tumoral activity in rat lungs. However, we cannot eliminate the possibility that other types of damage, as yet uncharacterized in terms of their mutagenic potential, can give rise to G:C-to-C:G transversions such as observed here.

As shown in Figure 4, the ethyl acetate fraction of chapéu-de-couro extract was strongly genotoxic. Several studies have shown that quercetin causes base-pair substitutions and frameshift mutations in Ames strains (Bjeldanes and Chang, 1977; Hatcher and Bryan, 1985; Makena et al., 2009), chromosomal aberrations and sister chromatid exchanges in CHO cells (Carver et al., 1983), and micronucleus formation in human lymphocytes in the absence or presence of metabolic activation (Caria et al., 1995). While the redox potentials of most flavonoid radicals are below those of superoxide and alkyl peroxide radicals (Jørgensen et al., 1998), their effectiveness in generating lipid peroxidation, DNA adducts, and mutations may be biologically relevant. Quercetin, an aglycone form of a flavonoid glycoside, was the most mutagenic compound to TA98 $S$. typhimurium strain (Hatcher and Bryan, 1985); this strain was also sensitive to the chapéu-de-couro extract. Quercetin is also mutagenic in test strains of $E$. coli (Makena et al., 2009). Particular attention should therefore be paid to quercetin since it is the most predominant aglycone flavonoid in the human diet, with an estimated human consumption of 4-68 mg/day based on epidemiological studies in the US (Hertog et al., 1993, 1995; Rimm et al., 1996; Knekt et al., 1997). Other compounds such as diterpenoids have also been isolated from E. macrophyllus (Kobayashi et al., 2000; Shigemori et al., 2002). A diterpenoid isolated from Sagittaria pygmaea showed antibacterial acitivity against oral pathogens, but no biological activities have been attributed to diterpenoids from E. macrophyllus. In 
the case of chapéu-de-couro extract, it is one of the main ingredients used to prepare a very popular soft drink (Mineirinho) widely consumed in Brazil.

In conclusion, our results indicate that chapéu-decouro extract is genotoxic and mutagenic in bacterial tests. The aglycones lutheolin and quercetin may be responsible for this activity and could be potentially carcinogenic in uncontrolled human consumption. Further studies are needed to evaluate the carcinogenicity of this extract in order to adequately assess the risks for human health.

\section{Acknowledgments}

We thank J.S. Cardoso and A.B. Silva for their expert technical support. This work was supported by $\mathrm{CNPq}$, CAPES and FAPERJ.

\section{References}

Akasaka S and Yamamoto K (1994) Hydrogen peroxide induces $\mathrm{G}: \mathrm{A}$ to T:A and $\mathrm{G}: \mathrm{C}$ to $\mathrm{C}: \mathrm{G}$ transversions in the supF gene of E. coli. Mol Gen Genet 243:500-505.

Ames BN and Gold LS (1991) Endogenous mutagens and the causes of aging and cancer. Mutat Res 250:3-16.

Ariza RR, Dorado D, Barbancho M and Pueyo C (1988) Study of the causes of direct-acting mutagenicity in coffee and tea using the Ara test in Salmonella typhimurium. Mutat Res 201:89-96.

Bjeldanes LF and Chang GW (1977) Mutagenic activity of quercetin and related compounds. Science 197:577-578.

Blanco M, Urios A and Martínez A (1998) New Escherichia coli WP2 tester strains highly sensitive to reversion by oxidative mutagens. Mutat Res 413:95-101.

Brandi G, Cattabeni F, Albano A and Cantoni O (1989) Role of hydroxyl radicals in Escherichia coli killing induced by hydrogen peroxide. Free Radic Res Commun 6:47-55.

Caria H, Chaveca T, Laires A and Rueff J (1995) Genotoxicity of quercetin in the micronucleus assay in mouse bone marrow erythrocytes, human lymphocytes, V79 cell line and identification of kinetochore-containing (CREST staining) micronuclei in human lymphocytes. Mutat Res 343:85-94.

Carver JH, Carrano AV and McGregor JT (1983) Genetic effects of the flavonols quercetin, kaempferol, and galangin on Chinese hamster ovary cells in vitro. Mutat Res 113:45-60.

Costa Lopes L, Albano F, Augusto Travassos Naranja G, Marques Alves L, Silva FML, Souza PG, Araújo IM, Nogueira-Neto JF, Felzenszwalb I and Kovary K (2000) Toxicological evaluation by in vitro and in vivo assays of an aqueous extract prepared from Echinodorus macrophyllus leaves. Toxicol Lett 116:189-198.

Cupples CG and Miller JH (1989) A set of lacZ mutations in Escherichia coli which allow rapid detection of each of the six base substitutions. Proc Natl Acad Sci USA 86:5345-5349.

Cupples CG, Cabrera M, Cruz C and Miller JH (1990) A set of lacZ mutations in Escherichia coli that allow rapid detection of specific frameshift mutations. Genetics 125:275-280.

Fonseca CAS, Leal J, Costa SS and Leitão AC (1994) Genotoxic and mutagenic effects of guarana (Paullinia cupana) in prokaryotic organisms. Mutat Res 321:165-173.
Fonseca CAS, Otto SS, Paumgartten FJR and Leitão AC (2000) Nontoxic mutagenic and clastogenic activities of matechimarrão (Ilex paraguariesis). J Environ Pathol Toxicol Oncol 19:333-346.

Fujita Y, Wakabayashi K, Nagao M and Sugimura T (1985) Implication of hydrogen peroxide in the mutagenicity of coffee. Mutat Res 144:227-230.

Gatehouse D, Haworth S, Cebula T, Gocke E, Kier L, Matsushima T, Melcion C, Nohmi T, Ohta T, Venitt S et al. (1994) Recommendations for the performance of bacterial mutation assays. Mutat Res 312:217-233.

Halliwell B and Gutteridge JMC (1989) Free Radicals in Biology and Medicine. 2nd edition. Clarendon Press, Oxford, $936 \mathrm{pp}$.

Harman D (1956) Aging: A theory based on free radical and radiation chemistry. J Gerontol 11:298-300.

Hatcher JF and Bryan GT (1985) Factors affecting the mutagenic activity of quercetin for Salmonella typhimurium TA98: Metal ions, antioxidants and $\mathrm{pH}$. Mutat Res 148:13-23.

Hertog MG, Feskens EJ, Hollman PC, Katan MB and Kromhout D (1993) Dietary antioxidant flavonoids and risk of coronary heart disease: The Zutphen Elderly Study. Lancet 342:1007-1011.

Hertog MG, Kromhout D, Aravanis C, Blackburn H, Buzina R, Fidanza F, Giampaoli S, Jansen A, Menotti A and Nedeljkovic S (1995) Flavonoid intake and long-term risk of coronary heart disease and cancer in the seven countries study. Arch Intern Med 155:381-386. [Erratum in Arch Intern Med 155:1184].

Imlay JA, Chin SM and Linn S (1988) Toxic DNA damage by hydrogen peroxide through the Fenton reaction in vivo and in vitro. Science 240:640-642.

Jørgensen LV, Cornett C, Justesen U and Skibsted L (1998) Two-electron electrochemical oxidation of quercetin and kaempferol changes only the flavonoid C-ring. Free Radical Res 29:339-350.

Knekt P, Järvinen R, Seppänen R, Heliövaara M, Teppo L, Pukkala E and Aromaa A (1997) Dietary flavonoids and the risk of lung cancer and other malignant neoplasms. Am J Epidemiol 146:223-230.

Kobayashi J, Sekiguchi M, Shimamoto S, Shigemori H and Ohsaki A (2000) Echinophyllins C-F, new nitrogen-containing clerodane diterpenoids from Echinodorus macrophyllus. J Nat Prod 63:1576-1579.

Leitão A and Braga RS (1994) Mutagenic and genotoxic effects of mate (Ilex paraguariensis) in prokaryotic organisms. Braz $\mathrm{J}$ Med Biol Res 27:1517-1525.

Makena PS, Pierce SC, Chung KT and Sinclair SE (2009) Comparative mutagenic effect of structurally similar flavonoids quercetin and taxifolin on tester strains Salmonella typhimurium TA102 and Escherichia coli WP2 uvrA. Environ Mol Mutagen 50:451-459.

Maron DM and Ames BN (1983) Revised methods for the Salmonella mutagenicity test. Mutat Res 113:173-215.

McBride TJ, Preston BD and Loeb LA (1991) Mutagenic spectrum resulting from DNA damage by oxygen radicals. Biochemistry 30:207-213.

McBride TJ, Schneider JE, Floyd RA and Loeb LA (1992) Mutations induced by methylene blue plus light in singlestranded M13mp2. Proc Natl Acad Sci USA 89:6866-6870. 
Miller JH (1992) A Short Course in Bacterial Genetics. Cold Spring Harbor Laboratory Press, Cold Spring Harbor, $456 \mathrm{pp}$.

Moreau P, Bailone A and Devoret R (1976) Prophage $\lambda$ induction in Escherichia coli $\mathrm{K} 12$ envA $u v r \mathrm{~B}$ : a highly sensitive test for potential carcinogens. Proc Natl Acad Sci USA 73:3700-3704.

Murry V (1986) Transversion-specific purine analogue mutagens and the mechanism of hydroxylaminopurine mutagenesis. Mutat Res 177:189-199.

Pinto AC, Rego GC, Siqueira AM, Cardoso CC, Reis PA, Marques EA, Coelho MG and Carvalho Sabino KC (2007) Immunosuppressive effects of Echinodorus macrophyllus aqueous extract. J Ethnopharmacol 111:435-439.

Quillardet P and Hofnung M (1985) The SOS chromotest, a colorimetric bacterial assay for genotoxins: procedures. Mutat Res 147:65-78.

Quillardet P, Huissman O, D'Ari R and Hofnung M (1982) SOS chromotest, a direct assay of induction of SOS function in $E$. coli K-12 to measure genotoxicity. Proc Natl Acad Sci USA 79:5971-5975.

Retel J, Hoebee B, Braun JEF, Lutgerrink JT, Akker EVD, Wanamarta AH, Joenje H and Lafleu MVM (1993) Mutational specificity of oxidative DNA damage. Mutat Res 299:165182.

Rimm EB, Katan MB, Ascherio A, Stampfer MJ and Willett WC (1996) Relation between intake of flavonoids and risk for coronary heart disease in male health professionals. Ann Intern Med 125:384-389.
Rossman TG, Molina T and Meijer LW (1984) The genetic toxicology of metal compounds: I. Induction of prophage in E.coli WP2s( $\lambda$ ). Environ Mutagen 6:59-69.

Ruiz-Laguna J and Pueyo C (1999) Hydrogen peroxide and coffee induce G:CT:A transversions in the lacI gene of catalasedefective Escherichia coli. Mutagenesis 14:95-102.

Shigemori H, Shimamoto S, Sekiguchi M, Ohsaki A and Kobayashi J (2002) Echinodolides A and B, new cembrane diterpenoids with an eight-membered lactine ring from the leaves of Echinodorus macrophyllus. J Nat Prod 65:82-84.

Sugimura T (1982) Mutagens, carcinogens, and tumor promoters in our daily food. Cancer 49:1970-1984.

Tchou T and Grollman AP (1993) Repair of DNA containing the oxidatively damaged base, 8-oxoguanine. Mutat Res 299:277-287.

Valko M, Leibfritz D, Moncol J, Cronin MT, Mazur M and Telser $\mathrm{J}$ (2007) Free radicals and antioxidants in normal physiological functions and human disease. Int J Biochem Cell Biol 39:44-84.

Vogel HJ and Bonner DM (1956) Acetylornithinase of Escherichia coli: partial purification and some properties. J Biol Chem 218:97-106.

Zhang Z, Chang Q, Zhu M, Huang Y, Ho WKK and Chen Z (2001) Characterization of antioxidants present in hawthorn fruits. J Nutr Biochem 12:144-152.

Associate Editor: Catarina S. Takahashi

License information: This is an open-access article distributed under the terms of the Creative Commons Attribution License, which permits unrestricted use, distribution, and reproduction in any medium, provided the original work is properly cited. 